\title{
アイヌ人骨の自然人類学的研究と その課題
}

篠田謙一

明治期に始まる日本の人類学研究の中で、ア イヌ民族の系統と由来は常に重要な研究分野 として注目されてきた。その研究の基礎となる 人骨の収集も明治から昭和にかけて継続的に 行われ、現在では全国の大学研究機関に 1,500 体を越えるアイヌ人骨が収集されている。これ らの人骨を用いた自然人類学研究から、アイヌ 民族の系統や現代日本人の成立に関する様々 な学説が提示されてきたが、本稿では、こうし た研究の成果と将来の展望を紹介し、人骨研究 が社会に果たす役割について説明する。

\section{現在の人骨研究の二つの側面}

現在の自然人類学では、人骨を用いた研究は 主として二つの異なる目的を持って行われて いる。ひとつは従来から行われている集団の成 立や変遷を追求するもので、人骨の形態学的な 特徵を数量化して比較することで、集団の系統 を明らかにしていく研究である。アイヌ民族の 成立の経緯や、あるいは本土日本人を始めとす る周辺集団との関係などは、この手法によって 追求されてきた。

これに対し、1980年代以降には人骨に現れ る様々な変異を読み取ることで、過去の集団の 社会や生活を復元する生物考古学的研究が盛 んに行われるようになってきた。人骨に残され た病変などの特徵は、古代集団の生業、健康状 態などを推測する貴重なデー夕となることが
分かってきたことで、この分野の研究は大きく 進展した。

北海道における成果の一例として、縄文時代 後期の遺跡である入江貝塚から出土した二十 歳前後で死亡した女性の事例が挙げられる。こ の人物は幼少期にポリオに罹患したと推測さ れ、数年間にわたって寝たきりの生活をしてい たことが、四肢骨の形態などから判明している。 この事例は狩猟採集社会であってもハンディ キャップを持った人間のケアをしていたこと を示しており、当時の社会を考える上での重要 な情報を提供することになった。

アイヌ集団については、虫歯の頻度や、幼少 期の栄養障害を示す指標であるエナメル質減 形成などについての先行研究がある。最近では 伊達市有珠四遺跡から出土したアイヌ人骨の 一個体（青年男性）に、脊椎性の結核と思われ る所見が見られたという報告がある。この個体 の埋葬年代は、火山灰の層序から $1640 ＼mathrm{~ 63 年 ~}$ の間と限定でき、現在のところアイヌ民族とし ては最も古い結核罹患例となっている。しかし ながら前述した形質による集団の形成史や系 統論の研究と比べると、この分野の研究は極め て少ない。更に研究を進めることができれば、 アイヌの人々の過去の生活の様子を詳細に再 現することが可能になるだろう。 


\section{アイヌ集団の系統論の進展}

現在主流となっている日本人の成立論は、骨 形態の研究から導かれた「二重構造モデル」で ある。これは全国的に均一であった縄文集団の 社会に、弥生時代になって大陸から水田稲作と 金属器を持った渡来系弥生人が進入し、彼らが 在来の縄文人と混血しながら全国に広がるこ とによって本州・九州・四国に居住するいわゆ る本土日本人が形成されたと考える学説であ る。一方、稲作農耕の伝播が遅れた北海道や琉 球列島は混血の影響をあまり受けずに、現在で も縄文の血を色濃く残した人たちが居住して いると考えている。アイヌ集団の成立もこの文 脈の中で解釈され、アイヌ集団は縄文人の子孫 と捉えられている (写真)。ただし、この学説 は日本列島集団の多様性や、南北の集団に見ら れる形態的な類似性などをうまく説明している ものの、日本人の成立を統一的に説明するため

\section{北海道の縄文人とアイヌ人骨}

顔面部を側方から見たところ。鼻根部の形態などが よく似ていることが分かる（写真提供・百々幸雄）

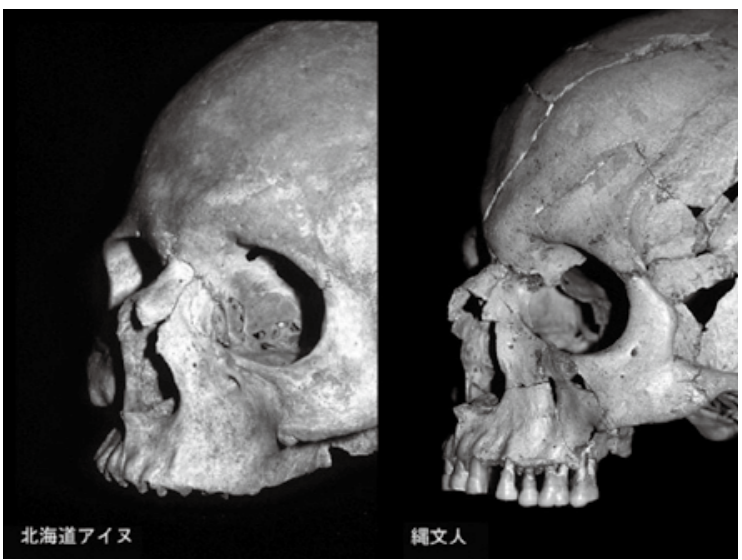

に、日本列島全体を中央と周辺地域という視点 で捉えていることには注意する必要がある。最 近では、このような単純なとらえ方では列島集 団の多様性を説明できないという指摘もある。

90 年代以降に行われた人骨の形態学的研究 は、アイヌ集団はおおむね縄文人に似ていると しているものの、相違点も指摘されており、現 在では単純に縄文人の直系の子孫であるとい う捉え方をする研究者は少ない。またアイヌ集 団自体の地域性について周辺集団との関連を 指摘する最新の形態学的研究もあり、アイヌ集 団の成立に関する新たな学説も提示されるよ うになっている。

\section{DNA分析の進展}

このように形態学的な研究でも従来のアイ 又観には変化が起きているが、近年盛んになっ たDNA分析では更に異なる形成史が語られて いる。まず現代人のDNA分析によって、二重 構造モデルが予想する列島の南北の集団の近 縁性は否定されている。アイヌ集団の持つミ トコンドリアDNAの系統には、沿海州やカム チャッカ半島の先住集団が持っている系統が かなりの割合で認められ、琉球列島集団とは際 だった相違を見せている。

最近、北海道で縄文時代から現代に至る集団 の遺伝的な変遷が調査された。その結果、アイ 又集団にはオホーツク文化人から引き継いた と考えられるDNAが相当な比率で含まれてい 
ることが明らかになり、縄文系集団とオホーツ ク文化人の合流によってアイヌ集団が形成さ れたというシナリオが提示されている。更に近 世アイヌ人骨のDNA分析の結果は、近隣集団 との間に遺伝的交流があったことを指摘して おり、DNA分析はアイヌ集団が縄文時代から 隔離されて現在に至っているという孤立した イメージが虚構であることを明らかにした。北 海道の先住集団も、本土日本人が在来の縄文系 の集団と稲作農耕集団である渡来系弥生人の 混合によって成立したように、様々な集団の遺 伝的交流の中で形成されてきたのである。

集団の遺伝子構成は様々な要因によって時 間と共に変化していく。たとえば他の集団の流 入や通婚圈の変化、あるいは戦争や疫病による 一時的な人口の減少とその後の回復などがあ ると、遺伝子構成は大きく変化する。人類学研 究では、これらの変化を捉えて集団の歴史を 再現していく。現時点でDNA分析によって描 かれている北海道の先住民集団の歴史は、解析 個体数が少ないこともあり、細部を詰めるには 至っていないが、今後更に多くの個体を解析し

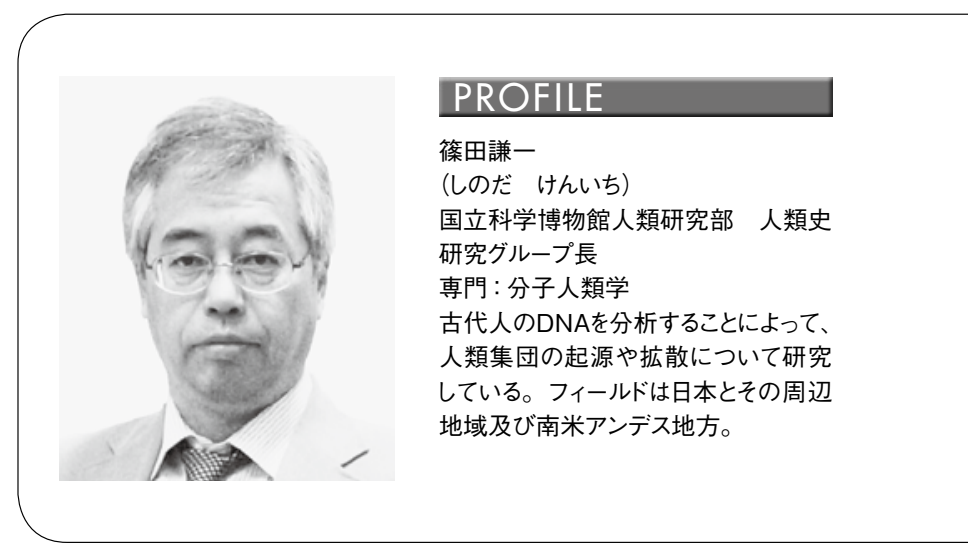

の人類学者は、全国各地で人骨を収集する努力 を続けてきた。その結果、これまでに 2 万体以 上の人骨が収集され、研究に供されている。一 方、アイヌ人骨に関しては前述したようにおよ そ1,500体が保管されている。古くは明治時代 から集められた人骨もあるが、その多くは大 正時代から第二次大戦後間もない時期に収集 された。このような先達が集めた人骨の研究に よって、アイヌ集団の系統論が組み立てられて きた。四は年代別に見たアイヌ人骨を用いた研 究論文の数を示したものである。これまでに 500 編以上が専門誌に発表されている。明治時 代の始めにはヨーロッパ人による論文が発表 されているが、それ以降は日本の研究者による 論文が大部分である。また、グラフからアイヌ

ていけば、アイヌ集団の地域性の 問題などについても情報を提供 することができるだろう。

\section{アイヌ人骨を用いた研究}

列島集団の起源や古代の生活 の様子を知るため、明治以来日本

\section{図 これまでに発表されているアイヌ人骨を用いた時代別の研究論文数}

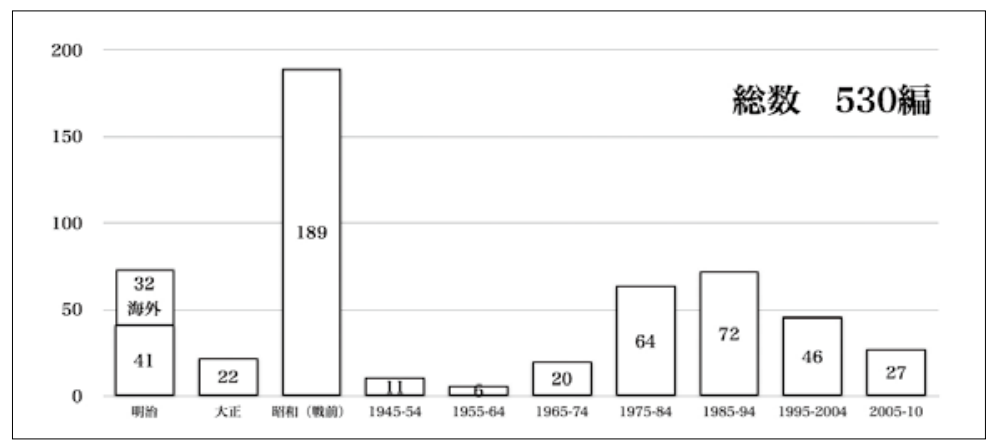


人骨の収集が盛んであった戦前には数多くの 論文が発表されていることが分かる。

このように収集されたアイヌ人骨から得られ た研究結果は、学問の世界には公表されてきて おり、その収集が研究目的であったことは間違 いない。ただし、収集の方法に関して言えば、 特に戦前のものは他の本土日本人の人骨とは違 い当事者であるアイ又の人たちに収集の目的 ないしはその意義を明らかにしないまま集めら れた人骨がかなりあることが知られている。

\section{人骨を用いた研究の重要性}

人骨は、集団の由来や、過去の社会、祖先の 生活を知ることのできるほとんど唯一の証拠 であるが故に、現代に生きる私たちにとって貴 重な資料であるという側面を持っている。また、 学問の必然として、これまでに行われた研究結 果も、方法の進歩やデータの追加によって結論 が変わっていく。真実を知るための努力は、常 に行われていかなければならず、そのための資 料として人骨を保存・継承していくことが必要 となる。

前述したように現在の自然人類学的研究は 系統論だけではなく、様々な手法を用いて、古 代社会の復元を目指すものになっているが、残 念ながらアイヌ人骨に関しては、この分野の研 究はほとんど行われていない。また、DNA解 析技術の進歩によって、古人骨から膨大な情報 量を持つ核DNAの情報も取り出すことができ
るようになっており、将来的にはより詳細な生 活史の復元も可能になることが予想される。更 に近年、様々な理化学的な手法が発達したこ とによって、従来の手法では知ることのできな かった過去の生活に関する情報を知ることが 可能になっている。これらの学問状況を考えれ ば人骨の持つ研究上の重要性は更に増してい ると言える。

\section{今後の人骨研究にむけて}

アイヌ人骨の収集に関しては、発掘の当事者 である研究者の日記などの記述等を見ると、現 在の基準に照らして倫理的な責任があるもの が存在することは明らかである。また、得られ た成果の周知は学問の世界に完結して、当事 者であるアイヌの人々に還元されることはな かった。これらのことは研究者として率直に反 省すべき点である。

いくつかの先進国では先住民の遺骨を埋め 戻すことで、その責任を果たそうとしている。 しかし、実は、これはその地域に成立の歴史を 持たない人々が考える解決の方法であって、そ のことが先住民の歴史も抹殺していることに 注意する必要がある。アイヌの人々も本土の日 本人もともに日本列島に成立の基盤を持って いるという点で、日本の事情は他の諸国とは大 きく異なっている。

人類学者は将来にわたって、私たちがどのよ うにこの列島で歴史を刻み、暮らしてきたかを 
知る努力をしていく責務があると考えている。 従って、我々は他の国々とは異なる解決策を模 索する必要があるが、そのためにはアイヌの 人々と研究者の間で、今後の研究のあり方、そ の意義についての真摰な話し合いが必要とさ れている。 